\title{
DEVELOPMENT OF FORMAL AND INFORMAL INSTITUTI- ONS IN THE CZECH REPUBLIC AND OTHER NEW EU MEMBER STATES BEFORE THEIR EU ENTRY: DID THE EU PRESSURE HAVE IMPACT?
}

\author{
Adam GERŠL*
}

\begin{abstract}
:
The paper compares the quality of the institutional framework of the Czech Republic with other new EU Member States and the EU 15 average using the World Bank data on Governance Indicators and argues that the pressure from the EU institutions during the accession negotiation period to reform the legal framework was not sufficient to improve significantly the business environment. Among factors that prevented the improvement of institutions the influence of strong interest groups, ineffective enforcement of legal rules and corruption are discussed and empirically illustrated using data on "state capture".
\end{abstract}

Keywords: business environment; institutions; EU enlargement; corruption

JEL Classification: K200, K400, P300

\section{Introduction}

The transition process in Central and Eastern Europe represents a unique example of a profound change of institutional framework within which economic and political processes take place. This process can be assessed as relatively successful, as eight of the former socialist countries completed their transition by entering the EU in 2004. This may be regarded as sound evidence that the "rules of the game", especially the legal framework, have been successfully reformed and are currently in line with generally accepted principles of democracy and market economy.

Nevertheless, there are still significant differences as to the extent to which formal rules are effectively enforced and to which informal rules support the formal ones. These differences exist not only between the new EU Member States and the "old" EU countries, but also across the new EU Member States themselves. In addi-

*) Charles University in Prague, Faculty of Social Sciences, Institute of Economic Studies, Opletalova 26, CZ -11000 Prague 1 and Czech National Bank, Na Př́kopě 28, CZ - 11503 Prague 1 (e-mail: adam.gers।@cnb.cz).

${ }^{\star *}$ ) The article was written with support from the Czech Republic Ministry of Education grant MSM 0021620841 and presented at the HWWA Workshop Die Interaktion der ökonomischen Kulturen und Institutionen im erweiterten Europa, Hamburg 30/6-1/7/2005. The author thanks Nils Goldschmidt and Viktor Vanberg for helpful comments. The findings, interpretations and conclusions expressed in this paper are entirely those of the author and do not represent the view of any of the above institutions. 
tion, empirical evidence suggests that the pattern of development over time also differs and that the development was not necessarily always positive.

Some authors argue that the general improvement of the institutional framework in Central and Eastern European countries has been mainly driven by the pressure from the EU institutions as these countries were negotiating their terms of accession during the late 1990s and early 2000s (Vachudova 2001; Moravcsik and Vachudova 2003). However, these studies fail to recognize that the EU pressure might have influenced the formal rules, but only to a limited extent the informal ones, not to speak about the way formal rules are enforced. As ineffective enforcement and unsuitable informal rules may create severe obstacles to the economic development, external pressure by the EU to change formal rules may have not been sufficient.

In this short paper the example of the Czech Republic is taken to argue that external pressure from the EU institutions has not been enough to improve the overall quality of institutional framework of the economy, especially in the realm of informal rules and rule enforcement. Using data from the World Bank and the European Bank for Reconstruction and Development, it is shown that the Czech Republic, despite its upfront place in macroeconomic performance, lags behind in an area of business environment, although some factor may contribute to some improvements in the near future.

The paper is organized as follows: in section 2 several ways to measure institutions are reviewed and discussed. Section 3 compares the quality of institutions in the Czech Republic with other new EU Member States and the old EU countries, using the most developed set of indicators as collected by the World Bank. In section 4 possible causes of relatively adverse position of the Czech Republic, as compared with other EU countries, are discussed and evidenced empirically. Section 5 concludes with an outlook for improvements.

\section{Measuring institutions}

Several attempts to measure the quality of institutions has been made during the last decade. Körner et al. (2002) review some of the most frequently used ones, among others the Corruption Perception Index constructed by Transparency International and Governance Indicators constructed by the World Bank Institute. The latter ones will be also used in this paper.

As institutions, i.e. rules that limit and influence behaviour of individuals on both economic and political markets, are qualitative variables, it is hard to measure them directly. Therefore an indirect approach is usually used: institutions are assessed on a given scale in terms of their working properties and results are aggregated into an index.

Körner et al. (2002) also shortly discuss advantages and disadvantages of different types of indices: first, an index that measures quality of institutions may be unique, i.e. based on data from a special survey, or composite, i.e. aggregating several already existing data and indices. Clearly, a composite index may have larger coverage, but can suffer under incompatibility of inputs and heterogeneity of methodologies across time or countries.

Second, indices may be objective, i.e. based on hard and measurable data such as an average length of a commercial trial, or subjective, i.e. based on respondents' subjective opinions. Whilst objective indices may be better comparable across countries, there is usually only limited number of aspects that can be measured objectively. Subjective indices allow measuring almost all aspects of institutional framework, but can suffer under serious bias of those who report to surveys, thus making an international comparison much more difficult. 
Third, subjective indices differ according to the respondents. They can be either locals, such as domestic business leaders, or external experts. Local people are surely more familiar with the business environment and local rules than external observers, but they may not be free from bias in their responses due to different cultural background across countries. On the other hand, external experts may assess the institutional framework more independently.

In addition to the typology presented by Körner et al. (2002), two other issues can be added. First, indices may differ in terms of what they measure. In principle, an index can measure to what extent existing institutions correspond to some commonly agreed standards or benchmarks, or it can measure how content people are with existing institutions and whether they consider them as appropriate or inappropriate. Information that can be used from correspondence to benchmarks may be rather helpful for foreign investors, while subjective opinions about appropriateness of institutions, as assessed directly by the individuals concerned, may be preferable as they better reflect individuals' interests and values that may differ across time and countries, also due to cultural differences.

Second, indices also differ in terms of whether they can disentangle three basic components of every institutional framework: formal institutions, their formal enforcement, and informal institutions. Goldschmidt and Zweynert (2005) emphasize the distinction between formal and informal rules that is usually made in the new institutional economics. Formal rules are legal acts that are embodied in the legal system of a country, while informal rules represent rather "code of conducts", unwritten rules of behaviour, traditions and cultural conventions. While formal rules are formally enforced via judiciary, informal rules are enforced only informally, through social and internal sanctions, such as loss of trust to those who renege on informal rules etc.

In general, most indices, especially the subjective ones, measure a mixture of formal and informal institutions and enforcement mechanisms. For example, a positive answer to a survey question such as "does regulatory agency in your area of business put obstacles to your business" may indicate that formal rules are not appropriate, or informal rules are the source of obstacles (such as corruption), or enforcement of formal rules does not work, or all three possibilities. On the other hand, several smartly designed questions may, at least to some extent, allow differentiating between the three components of an institutional framework.

In the next section we use a set of indices constructed by the World Bank called Governance Indicators. The word "governance" actually stands for institutional framework in general and the World Bank defines it as "the traditions and institutions by which authority in a country is exercised" (Kaufmann et al., 2005). They construct six aggregate governance indicators in three areas of governance. All six indicators are composite indicators, i.e. constructed by combining available indices, based on both subjective opinion polls and expert judgments, into an aggregate governance indicator via unobserved component model methodology. As coverage of the underlying surveys differs across countries and over time, the governance indicators are normalized (to zero average and unit variance) and for each country and period the estimate of the average and its standard error is computed. The indicators have been constructed biennially since 1996 and due to their normalization (i.e. the average is zero in all periods) they are not indicative about global trends in governance. However, next to cross-country comparison within one period, they also provide useful information about changes in countries' relative positions over time.

Table 1 shows the three areas of governance together with the corresponding governance indicators: 
Table 1

Governance Indicators

\begin{tabular}{|l|l|}
\hline Political process & $\begin{array}{l}\text { 1. Voice and Accountability } \\
\text { 2. Political Stability and Absence of Violence }\end{array}$ \\
\hline Government's policies & $\begin{array}{l}\text { 3. Government Effectiveness } \\
\text { 4. Regulatory Quality }\end{array}$ \\
\hline Respect of citizens & $\begin{array}{l}\text { 5. Rule of Law } \\
\text { 6. Control of Corruption }\end{array}$ \\
\hline
\end{tabular}

Kaufmann et al. (2005) describe the content of the indicators. In the area of political process, i.e. the process by which government are selected, monitored and replaced, two indicators are constructed: Voice and Accountability measures various aspects of the political process, civil liberties, political rights, and the independence of the media, while Political Stability and Absence of Violence measures perceptions of the likelihood that the government in power will be destabilized or overthrown by unconstitutional or violent means.

The second area covers indicators that measure the capacity of the government to effectively formulate and implement sound policies. Government Effectiveness measures the quality of public service provision, the quality of bureaucracy, the competence of civil servants, the independence of the civil service from political pressures, and the credibility of the government's commitment to policies. In contrast, Regulatory Quality is focused on the policies themselves and measures to what extent government policies are market-friendly and the perceptions of the burdens imposed by excessive regulation on private businesses.

The last area includes two indicators that measure the respect of citizens for the institutions that govern their interaction. Rule of Law is a proxy for the degree of confidence individuals have in rules and covers perceptions of the incidence of crime, the effectiveness and predictability of the judicial branch, and the enforceability of contracts. Finally, Control of Corruption measures perception of corruption, reaching from small bribery up to grand corruption through which private agents corrupt politicians in order to influence the content of new law and regulations.

\section{The Quality of Institutions in the Czech Repub- Iic: The Message of Governance Indicators}

During the late 1990s and in the run-up phase before the EU entry between 2000 and 2004, the legal framework in the future new EU Member States was considerably reformed and altered according to requirements of the EU institutions. This external pressure during the negotiation period may have contributed to some improvements in the general institutional framework, but the effect on enforcement mechanisms and on the informal rules may have been less significant or even negligible. Following charts show the change in the six Governance Indicators between 1996 and 2004. As already mentioned, the values are informative only about the countries' relative positions.

Figure 1 shows the indicator Voice and Accountability, a proxy for the quality of democracy. This indicator improved in all new EU Member States between 1996 and 2004, with the exception of the Czech Republic and Cyprus. Nevertheless, the values for 2004 oscilate around one in all new EU countries and the differences are quite small. Still, however, the Czech Republic belonged to the worse half in 2004. In comparison to the EU15 average, the new EU countries still lag behind. 
Figure 1

Voice and Accountability

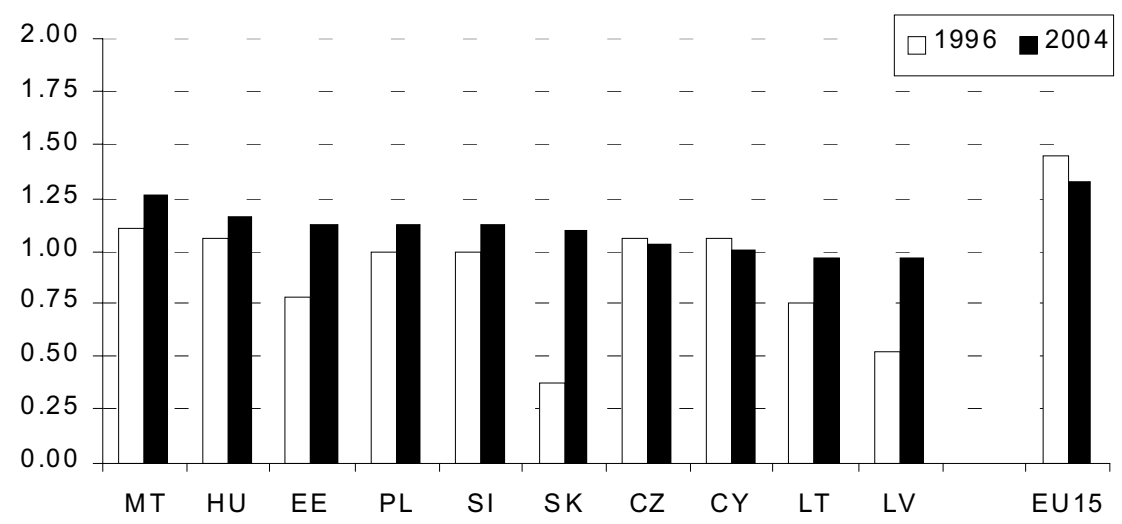

Source: World Bank (Governance Indicators).

Figure 2 reveals much more heterogeneous picture as regards the performance in the indicator Political Stability and Absence of Violence. Here some of the new EU Member States outperform or approach the EU15 average, probably due to the political stability component of the indicator. Again, the Czech Republic had worsened and belonged to the worse group in 2004, but the distance from the better performing countries is very small. Overall, six out of the ten new EU countries improved, the rest worsened between 1996 and 2004.

Figure 2

Political Stability and Absence of Violence

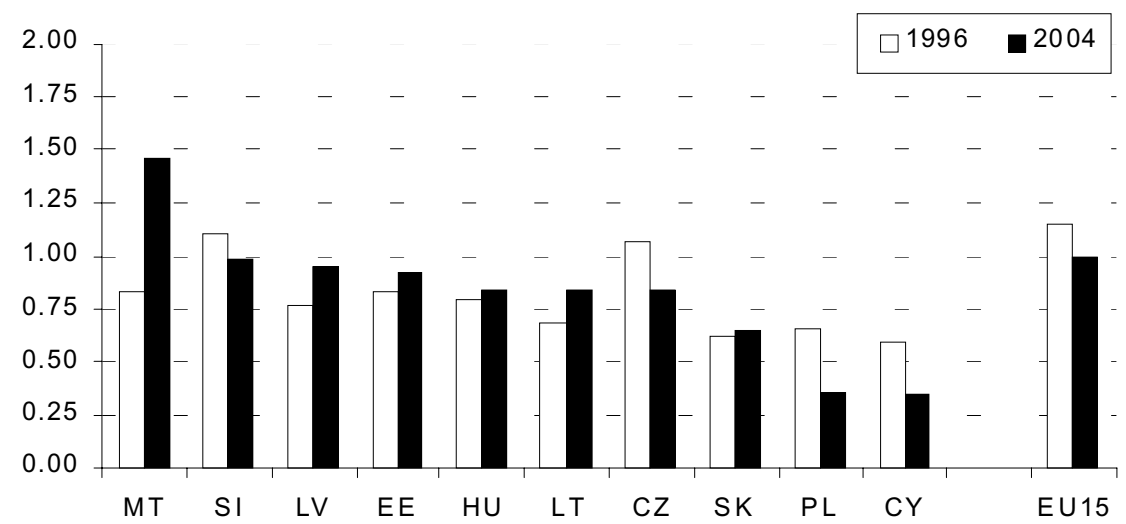

Source: World Bank (Governance Indicators).

Figure 3 indicates that government effectiveness is in the new EU countries much lower than in the EU15 countries. However, in six new EU Member States this indicator improved between 1996 and 2004, in some of them even significantly (Lithuania, Latvia, and Slovakia). Again, the Czech Republic belongs to the worse five out of the ten and the indicator had slightly worsened. 
Figure 3

Government Effectiveness

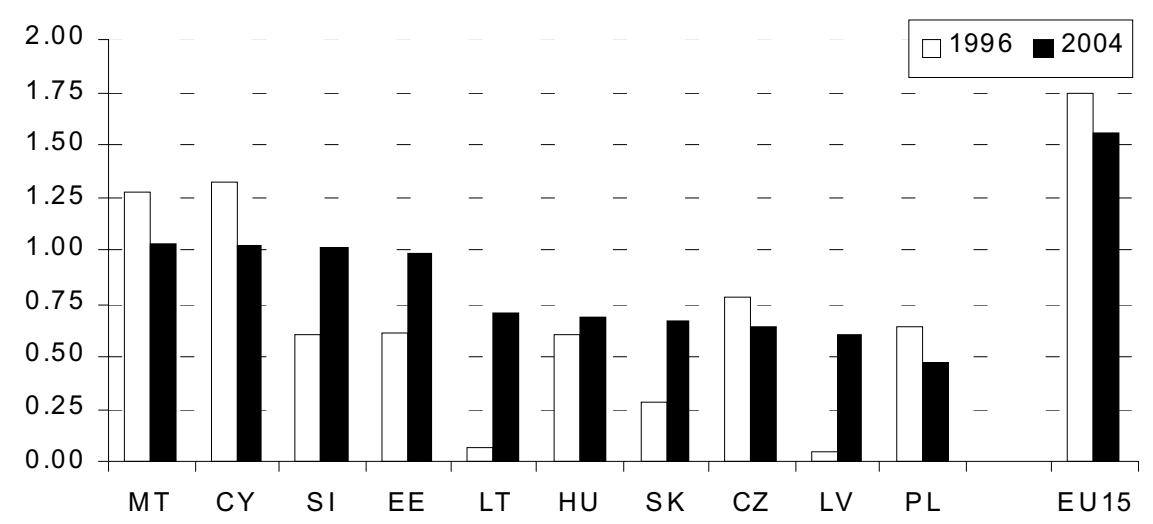

Source: World Bank (Governance Indicators).

Figure 4 shows an interesting picture. Regulatory Quality relatively improved in all new EU countries between 1996 and 2004 with the exception of the Czech Republic, where regulatory quality had worsened. Some of the new EU countries even outperform (Estonia) or approach (Malta, Cyprus, Hungary) the EU15 average, but most of them underperform. Again, the Czech Republic is not among the first five.

Figure 4

Regulatory Quality

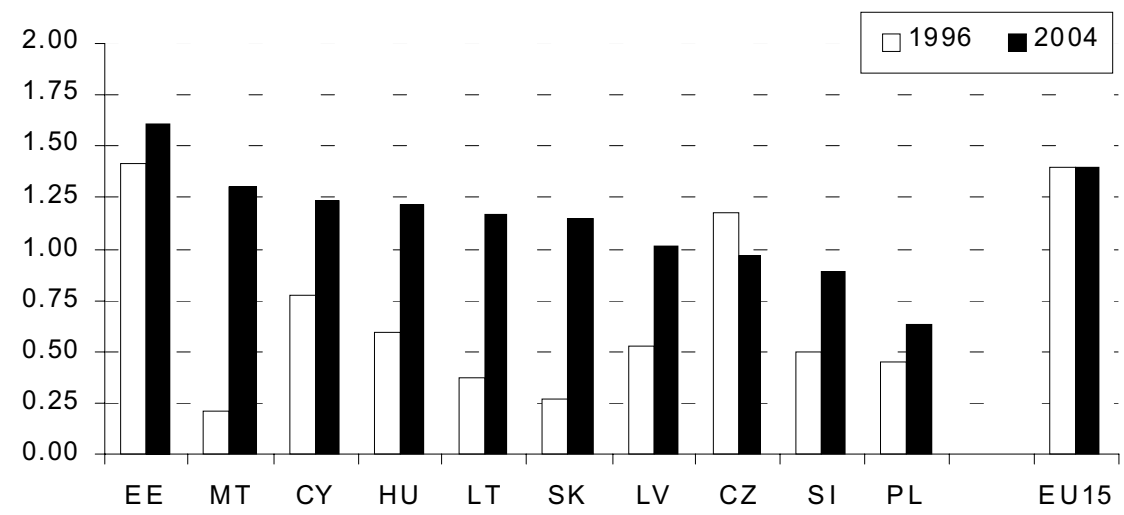

Source: World Bank (Governance Indicators).

Figure 5 shows that the indicator Rule of Law has improved in all new EU countries, in some of them even significantly (Malta, Lithuania, and Slovakia). In the Czech Republic, similarly to Poland, the indicator had improved only slightly. The new EU countries were still below the EU 15 average in 2004, with the Czech Republic on the place six out of ten. 
Figure 5

\section{Rule of Law}

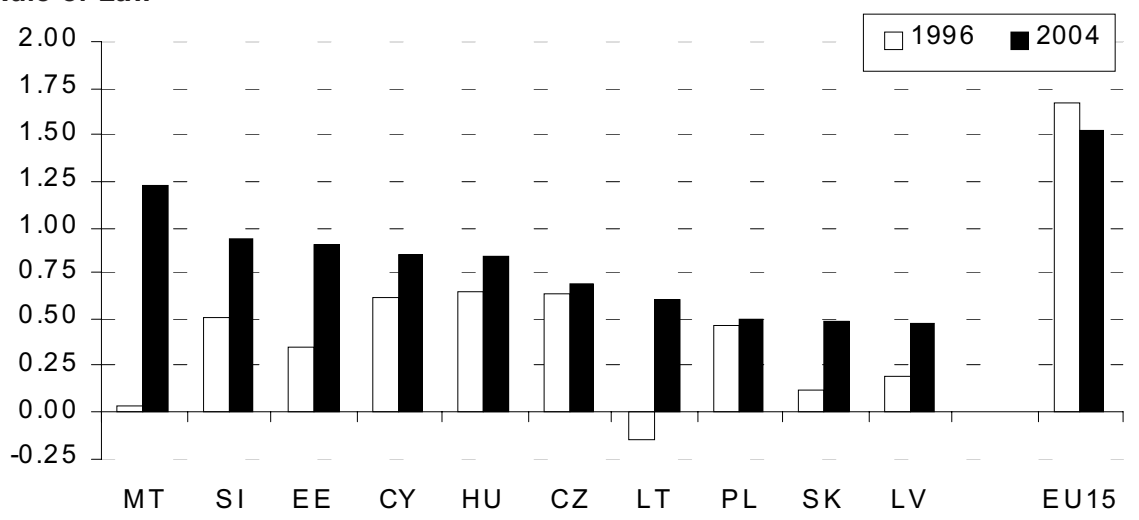

Source: World Bank (Governance Indicators).

Figure 6 suggests that the corruption remains a problem in most new EU countries, all of them significantly underperforming the EU15 average in 2004. Between 1996 and 2004, the development was rather heterogeneous: five countries had improved, while five had worsened. The Czech Republic, followed only by Latvia and Poland, closed the group of the new EU Member States in 2004.

Figure 6

Control of Corruption

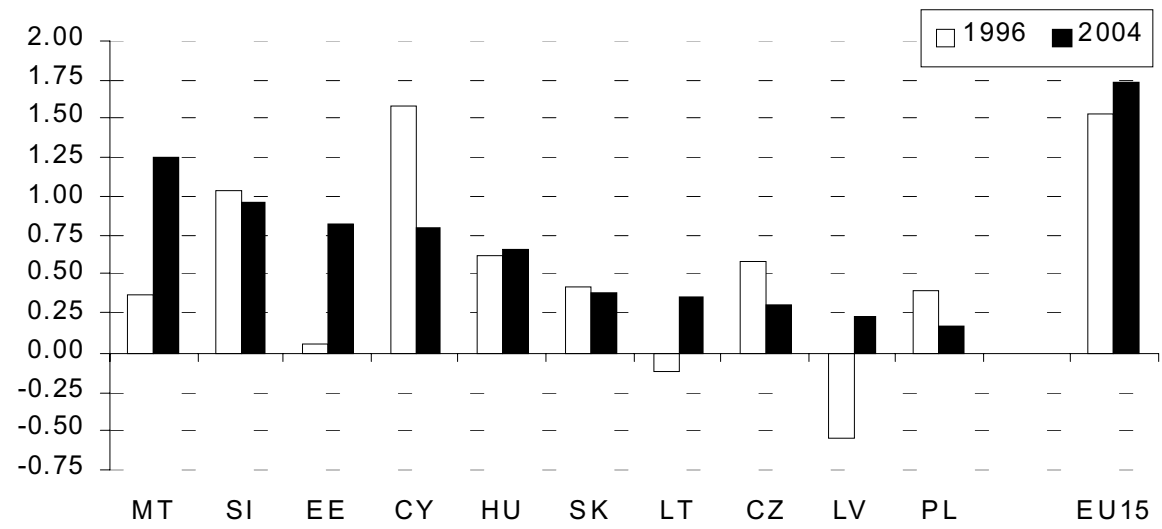

Source: World Bank (Governance Indicators).

Figure 7 puts the results on Control of Corruption into the perspective of the degree of economic development of the countries, as measured by the GDP per capita in purchasing power standards. The chart suggests that there is an apparent positive relationship between control of corruption and economic development. Countries that have high degree of economic development also have low corruption, but it is of course difficult to reveal the causality link. In any case, the Czech Republic is an outlier. The GDP per capita is the fourth highest among the new EU Member States, approaching $70 \%$ of the EU25 average, but it underperforms in Control of Corruption in comparison for example to countries like Estonia or Hungary. 
Figure 7

Corruption versus GDP per capita

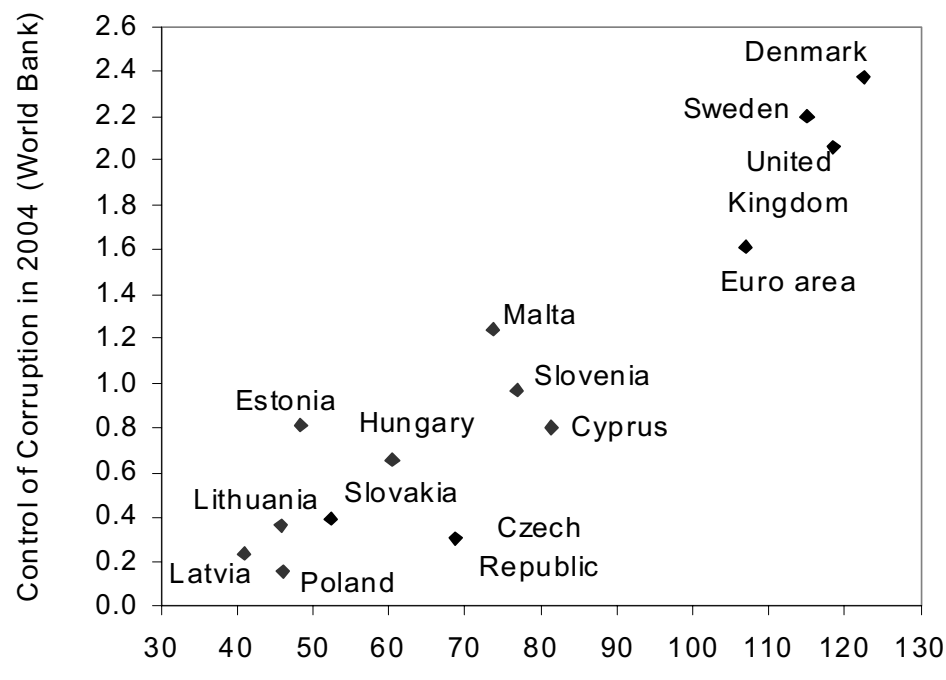

GDP per capita in Purchasing Power Standards in 2003

(in \% of EU 25)

Source: World Bank (Governance Indicators); Eurostat.

Overall, as can be seen from the previous charts, the Czech Republic, a champion as regards macroeconomic performance and inflow of foreign direct investment ranged quite bad as regards the institutional quality. However, the results of the Governance Indicators must be interpreted very carefully. Three arguments can be mentioned that slightly weaken the message of the Governance Indicators.

First, it is difficult to compare the countries' relative positions over time. A slight worsening of an indicator for the Czech Republic could emerge despite factual improvement, as it might be a result of all other countries having improved more than the Czech Republic. Nevertheless, this is also informative about the relative development.

Second, as mentioned elsewhere (EBRD 2002), the business cycle may have a strong effect on perception of the business environment. As the Czech Republic experienced a slight recession in 1997 - 1998, this may have biased the indicators downward. Nevertheless, in 2004 the Czech Republic experienced a robust economic growth comparable to the one of 1996, so that the figures - at least to some extent - should be comparable.

Third, a worsening of an indicator may also signal that individuals change the perception of the issue. This might have been the case with the Control of Corruption. It is quite possible that the size of corruption, hardly measurable, was the same in 1996 and 2004, but in the recent years, individuals became more sensitive to the issue due to quite frequent public discussion, media coverage, etc. However, as one of the triggers for more discussion about corruption was also the critique by the EU institutions, it is questionable whether this would have had effect only on the Czech Republic and not on the other new EU Member States.

Having in mind the just mentioned caveats, the Governance Indicators are still informative about a relatively worse position of the Czech Republic in institutional 
performance, both in comparison to the peer countries and the EU15. However, the pressure from the EU institutions to reform and put in line the formal rules with the EU15 between 1996 and 2004 definitely must have had some impact on the quality of formal rules. Thus, the adverse position of the Czech Republic in the institutional comparison may reflect three deficits in the institutional framework: despite the compatibility with acquis communitaire, the formal rules could be still inappropriate, or the formal rules are not effectively enforced, or the informal rules may be inappropriate. In the following section we try to find out which of the component is to be blamed.

\section{Why Does the Institutional Framework in the Czech Republic Lag Behind?}

We argue that the unsatisfactory relative position of the Czech Republic's institutional performance is due to a combination of two main factors that have had impact on all three components of an institutional framework. The first factor is the inherited informal rules from the shortage economy of socialism, a phenomenon called path dependency. This is nicely mirrored in the Control of Corruption indicator. Corruption was a frequently used means in the shortage economy through which economic agents got access to scarce means. This way of behavioir has persisted until now, mainly in dealing with public servants and officials.

The second factor was not inherited, but an unintended by-product of the selected strategy of economic transition. Privatization "without capital", i.e. to domestic entities that had either weak corporate governance (investment funds), or limited motivation to invest into the purchased company when buying it via credit from banks (managers), together with state ownership of big banks, leading to repeated extension of loans to otherwise non-viable but "socially" important employers, have created strong interest groups (Kouba et al., 2004). These interest groups opposed a number of needed institutional reforms of business environment, such as better bankruptcy law, quicker resolving of business disputes via courts, etc.

A combination of these two factors had an adverse effect on the whole institutional framework. First, the interest groups managed to influence the legislation to their interest, effectively using corruption or other means of influence on politicians. However, how this could have been possible during a period of EU pressure to reform legal framework? Three reasons may be mentioned: first, the variability of legal frameworks within the EU is large, reflecting various political, economic and cultural traditions. Thus, a legal act that is in line with European standards can still work inefficiently if it does not reflect reality. Second, the interest groups could have slowed down the whole process of the reforms, pushing for derogations or exceptions. Third, the interest groups may have also influenced the interpretation of legal rules in the court system.

Second, the interest groups may have had impact on enforcement of the legal rules via judiciary. Using different sorts of corruption and means of influence, they have effectively frozen or at least considerably prolong the disputes in courts. According to a recent World Bank study devoted to the business environment, an average time to go through insolvency, where an active role of a court is presumed, is around 9 years (!) in the Czech Republic (World Bank 2004), compared to Estonia (3 years), Hungary (2 years) or Germany (1 year).

Third, because of still inappropriate formal rules and/or their inefficient enforcement, informal rules, among them mainly corruption, have become a substitute of formal rules for "getting things done". Thus, instead of limiting corruption, inherited informal practices continued to be effective behavioral strategy vis-à-vis public ser- 
vants during the 1990s and also in the 2000s. The EU pressure was not enough strong to eliminate this business-environment-harming phenomenon.

The significant influence of interest groups in the Czech Republic can be illustrated by results of a survey called BEEPS (Business Environment and Enterprise Performance Survey) that was conducted by the World Bank and the EBRD in 1999 and 2002 in more than 20 transition countries (Hellman et al., 2000; EBRD, 2002). In this survey, local business people were asked to assess several aspects of business environment, including the possibility of firms to influence the framework within which they operate.

The next Table 2 shows to what extent "state capture", i.e. shaping the formation of the basic rules of the game through illicit and non-transparent private payments to public officials, exists in individual countries. The state capture is measured indirectly, i.e. as the share of firms which report a direct impact on their business from the purchase of legal acts and not as the share of firms engaging in state capture.

As Table 2 shows, the capture index decreased in almost all Central and Eastern European new EU Member States, with the exception of Slovenia, between 1999 and 2002. However, in 1999, the Czech Republic with Lithuania reached fourth worst place, after Latvia, Slovakia and Poland, and remained there also in 2002, now with Slovenia, after Latvia, Slovakia and Lithuania. This ordering is quite similar across the individual component of the State Capture index.

Table 2

State Capture (in \%)

\begin{tabular}{|lc|c|c|c|c|c|c|c|}
\hline & & $\begin{array}{c}\text { Parliamen- } \\
\text { tary votes }\end{array}$ & $\begin{array}{c}\text { Presidential/ } \\
\text { Government } \\
\text { decrees }\end{array}$ & $\begin{array}{c}\text { Central } \\
\text { Bank }\end{array}$ & $\begin{array}{c}\text { Criminal } \\
\text { Courts }\end{array}$ & $\begin{array}{c}\text { Commercial } \\
\text { Courts }\end{array}$ & $\begin{array}{c}\text { Party } \\
\text { Finance }\end{array}$ & $\begin{array}{c}\text { Capture } \\
\text { Index }\end{array}$ \\
\hline Czech & 1999 & 18 & 11 & 12 & 10 & 9 & 6 & 11 \\
Republic & 2002 & 6 & 6 & 4 & 10 & 13 & 10 & 8 \\
\hline Estonia & 1999 & 14 & 7 & 8 & 8 & 8 & 17 & 10 \\
& 2002 & 4 & 7 & 4 & 4 & 4 & 10 & 6 \\
\hline Hungary & 1999 & 12 & 7 & 8 & 5 & 5 & 4 & 7 \\
& 2002 & 4 & 5 & 4 & 3 & 7 & 8 & 5 \\
\hline Latvia & 1999 & 40 & 49 & 8 & 21 & 26 & 35 & 30 \\
& 2002 & 18 & 23 & 9 & 18 & 19 & 22 & 18 \\
\hline Lithuania & 1999 & 15 & 7 & 9 & 11 & 14 & 13 & 11 \\
& 2002 & 11 & 13 & 3 & 9 & 13 & 13 & 10 \\
\hline Poland & 1999 & 14 & 10 & 6 & 12 & 18 & 10 & 12 \\
& 2002 & 5 & 5 & 4 & 4 & 7 & 11 & 6 \\
\hline Slovakia & 1999 & 20 & 12 & 37 & 29 & 25 & 20 & 24 \\
& 2002 & 10 & 16 & 5 & 17 & 21 & 16 & 14 \\
\hline Slovenia & 1999 & 8 & 5 & 4 & 6 & 6 & 11 & 7 \\
& 2002 & 8 & 10 & 4 & 5 & 9 & 11 & 8 \\
\hline
\end{tabular}

Source: World Bank (BEEPS).

Percentage of firms responding to a question "what impact does the sale of ... have on your firm" with "significant" or "very significant". 
However, Table 3 reveals that private payments are not the most frequent means how to influence the content of legislation.

Table 3

State Capture or Influence (in \%)

\begin{tabular}{|l|c|r|r|r|}
\hline \multirow{2}{*}{} & \multicolumn{2}{|c|}{ Captor firms } & \multicolumn{2}{c|}{ Influential firms } \\
\cline { 2 - 5 } & 1999 & 2002 & 1999 & 2002 \\
\hline Czech Republic & 6.5 & 6.7 & 10.4 & 29.6 \\
\hline Estonia & 4.9 & 12.5 & 21.0 & 13.0 \\
\hline Hungary & 4.0 & 9.1 & 2.3 & 6.8 \\
\hline Latvia & 14.1 & 12.7 & 26.4 & 12.7 \\
\hline Poland & 13.6 & 5.6 & 6.6 & 9.2 \\
\hline Slovakia & 9.0 & 12.3 & 7.9 & 5.6 \\
\hline Slovenia & 12.1 & 9.5 & 10.3 & 22.6 \\
\hline
\end{tabular}

Source: World Bank (BEEPS).

Captor firms: firms responding to "How frequently do firms in your line of business have to pay some irregular "additional payments" for any of the following? To influence the content of new laws, decrees and regulations" with "sometimes" and "more frequently".

Influential firms: firms responding to "How much influence does your firm have, when a new law, rule, regulation, or decree is being discussed" with "moderate influence" and more.

The share of captor firms in the Czech Republic was and is rather low when compared with other countries ${ }^{1)}$ On the other hand, the share of influential firms, i.e. firms that have capacity to affect the content of law, rules and regulations that would have a substantial impact on their business, without a necessity to pay to politicians or public officials, is relatively high in the Czech Republic, both in 1999 (third highest figure) and especially in 2002 (the highest figure). However, this way of influence may be considered as a sort of corruption as well, as influential firms may offer to public servants other, non-financial benefits (such as employment opportunities, free services, etc.).

If formal rules, even appropriate and business-friendly, are not effectively enforced, informal rules may substitute formal ones and make the business environment much less transparent. Table 4 supports the argument that the relatively large extent of informal corrupt practices in the Czech Republic may be due to ineffective enforcement of formal rules. The table shows how business people assess the court system.

The results are rather alarming. In 1999, no firm in the Czech Republic would have said that the court system had been fair and impartial and honest and uncorrupt, in contrast to other new EU countries from the Central and Eastern Europe.

1) This of course does not mean that the state capture is no issue in the Czech Republic, as the extent to which the state is captured is not necessarily a function of the number of firms that engage in this activity. As Hellmann et al. (2000) argue, in an extreme case, a single powerful firm can generate a much higher level of state capture than a number of smaller firms. 
Table 4

Perception of the Court System (in \%)

\begin{tabular}{|l|c|c|c|c|c|c|c|c|}
\hline \multirow{2}{*}{} & \multicolumn{4}{|c|}{ Broad perception } & \multicolumn{4}{c|}{ Extreme perception } \\
\cline { 2 - 9 } & \multicolumn{2}{|c|}{ Fair and impartial } & \multicolumn{2}{|c|}{ Honest and uncorrupt } & \multicolumn{2}{c|}{ Fair and impartial } & \multicolumn{2}{c|}{ Honest and uncorrupt } \\
\cline { 2 - 9 } & 1999 & 2002 & 1999 & 2002 & 1999 & 2002 & 1999 & 2002 \\
\hline $\begin{array}{l}\text { Czech } \\
\text { Republic }\end{array}$ & 29.7 & 26.7 & 20.3 & 25.7 & 0.0 & 2.9 & 0.0 & 3.7 \\
\hline Estonia & 64.6 & 50.9 & 67.3 & 58.0 & 5.5 & 6.9 & 5.8 & 7.1 \\
\hline Hungary & 67.5 & 55.3 & 67.5 & 55.9 & 15.3 & 10.0 & 22.5 & 9.5 \\
\hline Latvia & 31.6 & 36.5 & 30.8 & 25.8 & 2.2 & 2.2 & 2.3 & 3.1 \\
\hline Lithuania & 21.0 & 24.7 & 11.3 & 19.0 & 1.2 & 5.3 & 2.5 & 4.5 \\
\hline Poland & 44.9 & 31.7 & 43.9 & 30.2 & 4.3 & 2.7 & 6.8 & 2.4 \\
\hline Slovakia & 39.9 & 26.0 & 31.0 & 25.3 & 1.6 & 4.0 & 4.1 & 3.3 \\
\hline Slovenia & 66.4 & 42.6 & 62.2 & 46.6 & 11.5 & 4.5 & 13.4 & 4.9 \\
\hline
\end{tabular}

Source: World Bank (BEEPS).

Broad perception: firms responding to "How often do you associate the following descriptions with the court system in resolving business disputes?" with "frequently", "mostly" and "always"

Extreme perception: firms responding to "How often do you associate the following descriptions with the court system in resolving business disputes?" with "always"

This figure slightly improved between 1999 and 2002, but the situation is still far from an ideal. In the Czech Republic, only $27 \%$ of firms considered the court system as rather fair and impartial, and only $26 \%$ honest und uncorrupt, a third worse figure after Lithuania and Slovakia in 2002.

\section{Conclusions}

In this paper, it has been shown that the Czech Republic, otherwise a front-runner in macroeconomic performance, lags behind in the quality of the institutional framework within which economic processes take place. It is argued that this unsatisfactory result is due to a combination of inherited corruption practices, ineffective enforcement of formal rules, and a negative role of interest groups that formed themselves thanks to the selected strategy of transition.

One of the promising triggers for improvement in institutional performance had been the external pressure from the EU institution during the period of accession negotiations as was often mentioned. As has been illustrated by the results of the Governing Indicators and BEEPS survey of the World Bank and the EBRD, the EU pressure might have had some impact on formal rules, but was not sufficient to influence the effectiveness of their enforcement, and hereby also the extent to which individuals continue to use informal rules, such as corruption as substitutes to formal rules.

Nevertheless, the outlook for further improvements in the Czech Republic's institutional framework remains positive, and a part of this optimism may be subscribed also to the consequences of the EU entry. First, being an EU Member State, the court system is to some extent linked to the EU court system. Thus, the EU pres- 
sure on fair, impartial and quick resolving of business disputes may have disciplining effect on the enforcement of the formal rules.

Second, better enforcement of formal rules may pave the way for the move away from the informal rules and corruption to the formal ones. If, additionally, the corruption will be better controlled formally and punished, the informal rules in the sense of daily code of conduct may also improve quite quickly.

Third, the economic recession in 1997 - 1998 and the subsequent recovery had led to a number of bankruptcies and a change in the structure of the economy, also due to inflow of foreign direct investment mainly in $2000-2003$. Foreign companies prefer transparent business environment, fair and quick business resolving via court system and do not suffer under path dependency as regards informal rules. Their relative ease with which they can leave the country again has a disciplining effect on the politicians to work more on a business-friendly institutional framework.

Last, the privatization of big banks and the ongoing privatization of big and recently influential companies help to cut the links between private firms and the state and limit the state capture. This could finally free the hands of the state not to engage into non-transparent agreements with private firms, but to concentrate more on cultivation of the institutional framework and appropriate business environment.

References

EBRD (2002), Transition Report 2002. European Bank for Reconstruction and Development.

Goldschmidt, N., Zweynert, J. (2005), Kulturelle Faktoren in wirtschaftlichen Transformationsprozessen. Ein Überblick.

Hellman, J. S., Jones, G., Kaufmann, D. (2000), Seize the State, Seize the Day. State Capture, Corruption, and Influence in Transition. World Bank Policy Research Working Paper No. 2444.

Kaufmann, D., Kraay, A., Mastruzzi, M. (2005), Governance Matters IV: Governance Indicators for 1996 - 2004. World Bank, Washington.

Kouba, K., Vychodil, O., Roberts, J. (2004), Privatization without Capital. (In Czech). Studie narodohospodářského ústavu Josefa Hlávky No. 4/2004.

Körner, P., Kudrna, Z., Vychodil, O. (2002), Measuring the Quality of Business Environment in Central Europe. Merit Research Working ePaper No. 1/Finance a úvěr 12/2002.

Moravcsik, A., Vachudova, M. A. (2003), National Interests, State Power, and EU Enlargement. Center for European Studies Working Paper No. 97.

Vachudova, M. A. (2001), The Leverage of International Institutions on Democratizing States: Eastern Europe and the European Union. European University Institute Working Paper No. 2001/33.

World Bank (2004), Doing Business in 2004. Understanding Regulation. IBRD/World Bank, Washington. 